\title{
Secondary Sulfates from the Monte Arsiccio Mine (Apuan Alps, Tuscany, Italy): Trace-Element Budget and Role in the Formation of Acid Mine Drainage
}

\author{
Massimo D’Orazio *(D), Daniela Mauro, Marta Valerio and Cristian Biagioni (D) \\ Dipartimento di Scienze della Terra, Università di Pisa, Via Santa Maria 53, I-56126 Pisa, Italy; \\ daniela.mauro@dst.unipi.it (D.M.); marta.valerio@dst.unipi.it (M.V.); cristian.biagioni@unipi.it (C.B.) \\ * Correspondence: massimo.dorazio@unipi.it; Tel.: +39-050-2215709
}

Citation: D'Orazio, M.; Mauro, D.; Valerio, M.; Biagioni, C. Secondary Sulfates from the Monte Arsiccio Mine (Apuan Alps, Tuscany, Italy): Trace-Element Budget and Role in the Formation of Acid Mine Drainage. Minerals 2021, 11, 206. https:// doi.org/10.3390/min11020206

Academic Editor: Stefan Peiffer

Received: 18 January 2021

Accepted: 12 February 2021

Published: 15 February 2021

Publisher's Note: MDPI stays neutral with regard to jurisdictional claims in published maps and institutional affiliations.

Copyright: (c) 2021 by the authors. Licensee MDPI, Basel, Switzerland. This article is an open access article distributed under the terms and conditions of the Creative Commons Attribution (CC BY) license (https:/ / creativecommons.org/licenses/by/ $4.0 /)$.

\begin{abstract}
A suite of sulfate minerals from the Monte Arsiccio mine (Apuan Alps, Northern Tuscany, Italy), previously identified by using both X-ray diffraction and micro-Raman spectroscopy, was studied through inductively coupled plasma mass spectrometry (ICP-MS), in order to determine their trace-element content. Several elements ( $\mathrm{Tl}, \mathrm{Rb}, \mathrm{As}, \mathrm{Sb}, \mathrm{Co}, \mathrm{Ni}, \mathrm{Cu}, \mathrm{Zn}$, and $\mathrm{Cr}$ ) were found above the detection limits. Among them, some are important from an environmental perspective and may reach relatively high concentrations (e.g., $\mathrm{Tl}=1370-2988 \mu \mathrm{g} / \mathrm{g}$; As = 505-1680 $\mu \mathrm{g} / \mathrm{g}$ ). Thus, these sulfates may act as transient sinks for some of these potentially toxic elements, as well as for sulfate ions and acidity. Indeed, dissolution experiments revealed the ability of these secondary minerals to produce a significant $\mathrm{pH}$ decrease of the solutions, as well as the release of $\mathrm{Fe}, \mathrm{Al}$, and $\mathrm{K}$ as major ions. This work discusses the relation between the budget of trace elements and the crystal chemistry of sulfate minerals and provides new insights about the environmental role played by the sulfate dissolution in controlling the quality of water in acid mine drainage systems.
\end{abstract}

Keywords: sulfate minerals; trace elements; dissolution; acid mine drainage; Apuan Alps; Italy

\section{Introduction}

The weathering of pyrite $\left(\mathrm{FeS}_{2}\right)$, the most abundant and widespread sulfide mineral on the Earth's surface, is the dominant, yet very complex, process causing the acidification of natural waters and the release of many potentially toxic elements (PTEs) into the aqueous medium (e.g., [1,2]). The migration of the chemical components from pyrite (Fe, $\mathrm{S}$, and a series of minor and trace elements), and from the minerals of the acid-altered country rocks to water may often be mediated and controlled by the formation of secondary minerals. These latter phases, dominated by hydrated sulfates (see [3,4]), are generally soluble in water, to a various extent, and can host variable amounts of PTEs as a function of their crystal-chemistry and the nature of the pyrite ore and the country rocks. The key role played by secondary minerals in acid mine drainage (AMD) systems is well-known [1,2,5] Indeed, they can store or release sulfate ions, acidity, and PTEs, following the dry and wet season cycles [3]. In addition, the dissolution of sulfates containing $\mathrm{Fe}^{3+}$ can significantly enhance pyrite oxidation, as this ion is a faster oxidant than $\mathrm{O}_{2}$ [6].

Geochemical data collected on the pyrite ores from the Southern Apuan Alps (Northern Tuscany, Italy) revealed the occurrence of high $\mathrm{Tl}, \mathrm{Sb}, \mathrm{As}$, and $\mathrm{Hg}$ contents, as well as minor amounts of $\mathrm{Zn}, \mathrm{Cd}, \mathrm{Pb}, \mathrm{Ag}$, and $\mathrm{Cu}$ [7-9]. These results posed concerns about the release of these hazardous elements in the environment, as a consequence of pyrite weathering [10-12]. Indeed, pyrite ores from the Southern Apuan Alps are particularly prone to oxidation mainly due to the following factors: (1) their very fine grain size (usually $<10 \mu \mathrm{m})$; (2) the very high rainfall of the area $(>2000 \mathrm{~mm} / \mathrm{a})$ [13], coupled with the medium-to-high permeability of the rocks occurring in the hanging-walls of several pyrite ore bodies [14]; and (3) the widespread occurrence of populations of oxidizing bacteria 
inside the abandoned mining tunnels. The occurrence of sulfate assemblages, known since long time (e.g., [15]), has been overlooked up to the last decade, when a series of mineralogical studies, summarized in Biagioni et al. [16], were performed, highlighting the presence of complex sulfate associations.

Among the sulfate assemblages so far identified in the Apuan Alps ore deposits, our attention was focused on that recently discovered at the Monte Arsiccio mine [16]. This finding allowed the collection of a significant amount of sulfate samples, with euhedral crystals up to some $\mathrm{cm}$ in size, well-suited for a detailed description of their geochemistry. In addition, such a fully characterized material was used for a series of experiments permitting the assessment of the role played by sulfate dissolution in controlling the traceelement content and the $\mathrm{pH}$ of water in AMD systems, comparing these new data with those reported by previous authors (e.g., [17-20]).

\section{Geological Background}

The Monte Arsiccio mine (latitude $43^{\circ} 58^{\prime} \mathrm{N}$, longitude $10^{\circ} 17^{\prime} \mathrm{E}$ ) exploited one of the several small pyrite \pm baryte \pm iron oxide orebodies located in the southern sector of the Apuan Alps. These orebodies form a discontinuous mineralized belt of $\sim 10 \mathrm{~km}$ with a NE-SW orientation (Figure 1). Their geological setting and geochemical features have been summarized in previous works (e.g., [8,9]). From northeast to southwest, the main mining sites were Fornovolasco, Buca della Vena, Canale della Radice, Monte Arsiccio, and Pollone mines.

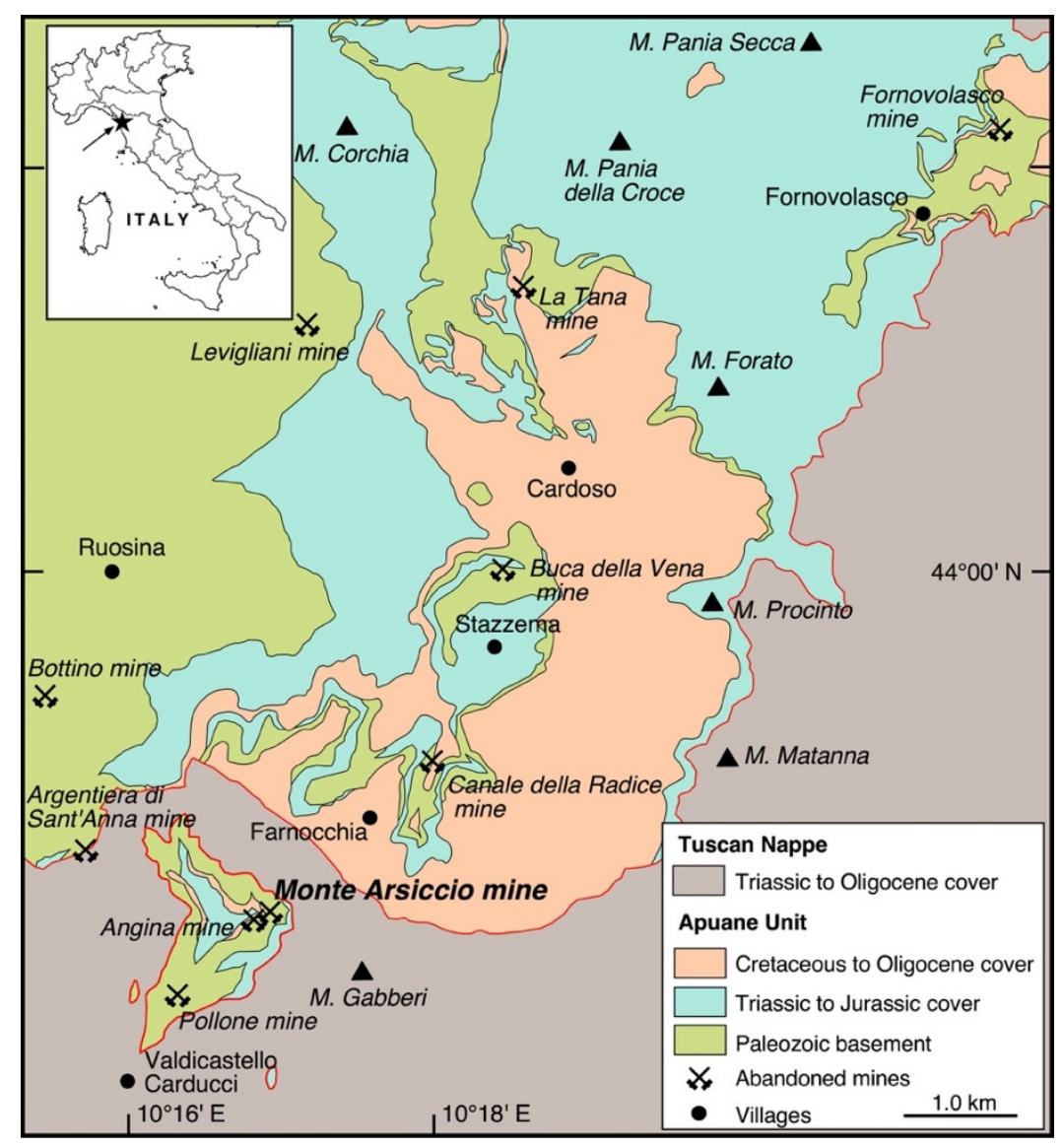

Figure 1. Simplified geological map of the Southern Apuan Alps, showing the location of the Monte Arsiccio mine and of the other abandoned mines of the area.

The Monte Arsiccio mine exploited the economically most important pyrite \pm baryte \pm iron oxide deposit in the Apuan Alps. The orebodies are hosted within a Paleozoic metavolcanic-metasedimentary sequence, locally tourmalinized, close to the contact with 
the overlying Triassic metadolostone ("Grezzoni" Formation), belonging to the Apuane Unit. The main exploited orebody at the Monte Arsiccio mine was represented by a lensshaped body, having a size of $120 \mathrm{~m} \times 90 \mathrm{~m} \times 80 \mathrm{~m}$ [21]. The mineralogical study of Monte Arsiccio allowed the identification of more than one hundred mineral species [22]. Among them, 18 different species can be classified as secondary sulfates (Table 1). Crystal-chemical data, as well as some field observations, have been reviewed by Biagioni et al. [16]. An additional brief description of the sampled outcrop, as well as the sulfate associations observed at the Monte Arsiccio mine, are given below.

Table 1. Secondary sulfate minerals from the Monte Arsiccio mine.

\begin{tabular}{|c|c|c|c|}
\hline Mineral & Ideal Chemical Formula & Mineral & Ideal Chemical Formula \\
\hline Alum-(K) & $\mathrm{KAl}\left(\mathrm{SO}_{4}\right)_{2}\left(\mathrm{H}_{2} \mathrm{O}\right)_{12}$ & Jarosite & $\mathrm{KFe}^{3+}{ }_{3}\left(\mathrm{SO}_{4}\right)_{2}(\mathrm{OH})_{6}$ \\
\hline Alunogen & $\mathrm{Al}_{2}\left(\mathrm{SO}_{4}\right)_{3}\left(\mathrm{H}_{2} \mathrm{O}\right)_{12} \cdot 5 \mathrm{H}_{2} \mathrm{O}$ & Khademite & $\mathrm{Al}\left(\mathrm{SO}_{4}\right) \mathrm{F}\left(\mathrm{H}_{2} \mathrm{O}\right)_{5}$ \\
\hline Anhydrite & $\mathrm{Ca}\left(\mathrm{SO}_{4}\right)$ & Krausite & $\mathrm{KFe}^{3+}\left(\mathrm{SO}_{4}\right)_{2}\left(\mathrm{H}_{2} \mathrm{O}\right)$ \\
\hline Coquimbite & $\mathrm{AlFe}^{3+}{ }_{3}\left(\mathrm{SO}_{4}\right)_{6}\left(\mathrm{H}_{2} \mathrm{O}\right)_{12} \cdot 6 \mathrm{H}_{2} \mathrm{O}$ & Magnanelliite & $\mathrm{K}_{3} \mathrm{Fe}^{3+}{ }_{2}\left(\mathrm{SO}_{4}\right)_{4}(\mathrm{OH})\left(\mathrm{H}_{2} \mathrm{O}\right)_{2}$ \\
\hline Epsomite & $\mathrm{Mg}\left(\mathrm{SO}_{4}\right)\left(\mathrm{H}_{2} \mathrm{O}\right)_{6} \cdot \mathrm{H}_{2} \mathrm{O}$ & Magnesiocopiapite & $\mathrm{MgFe}^{3+}{ }_{4}\left(\mathrm{SO}_{4}\right)_{6}(\mathrm{OH})_{2}\left(\mathrm{H}_{2} \mathrm{O}\right)_{14} \cdot 6 \mathrm{H}_{2} \mathrm{O}$ \\
\hline Giacovazzoite & $\mathrm{K}_{5} \mathrm{Fe}^{3+}{ }_{3} \mathrm{O}\left(\mathrm{SO}_{4}\right)_{6}\left(\mathrm{H}_{2} \mathrm{O}\right)_{9} \cdot \mathrm{H}_{2} \mathrm{O}$ & Melanterite & $\mathrm{Fe}^{2+}\left(\mathrm{SO}_{4}\right)\left(\mathrm{H}_{2} \mathrm{O}\right)_{6} \cdot \mathrm{H}_{2} \mathrm{O}$ \\
\hline Goldichite & $\mathrm{KFe}^{3+}\left(\mathrm{SO}_{4}\right)_{2}\left(\mathrm{H}_{2} \mathrm{O}\right)_{4}$ & Römerite & $\mathrm{Fe}^{2+} \mathrm{Fe}^{3+}{ }_{2}\left(\mathrm{SO}_{4}\right)_{4}\left(\mathrm{H}_{2} \mathrm{O}\right)_{14}$ \\
\hline Gypsum & $\mathrm{Ca}\left(\mathrm{SO}_{4}\right)\left(\mathrm{H}_{2} \mathrm{O}\right)_{2}$ & Scordariite & $\mathrm{K}_{8}\left(\mathrm{Fe}^{3+}{ }_{0.67 \square 0.33}\right)\left[\mathrm{Fe}^{3+}{ }_{3} \mathrm{O}\left(\mathrm{SO}_{4}\right)_{6}\left(\mathrm{H}_{2} \mathrm{O}\right)_{3}\right]_{2}\left(\mathrm{H}_{2} \mathrm{O}\right)_{11}$ \\
\hline Halotrichite & $\mathrm{Fe}^{2+} \mathrm{Al}_{2}\left(\mathrm{SO}_{4}\right)_{4}\left(\mathrm{H}_{2} \mathrm{O}\right)_{17} \cdot 5 \mathrm{H}_{2} \mathrm{O}$ & Voltaite & $\mathrm{K}_{2} \mathrm{Fe}^{2+}{ }_{5} \mathrm{Fe}^{3+}{ }_{3} \mathrm{Al}\left(\mathrm{SO}_{4}\right)_{12}\left(\mathrm{H}_{2} \mathrm{O}\right)_{18}$ \\
\hline
\end{tabular}

Note: minerals studied in this work are shown in bold.

\section{The Monte Arsiccio Sulfate Assemblage}

The sulfate assemblage occurring at the Monte Arsiccio mine is the result of the interaction between acid solutions derived from the pyrite oxidation and K-rich country rocks, mainly represented by quartz + muscovite + chlorite \pm tourmaline schist, with quartzite and tourmalinite.

The main features of this sulfate assemblage are as follows:

(1) The widespread occurrence of K-sulfates: it is worth noting that three new $\mathrm{K}-\mathrm{Fe}^{3+}$ sulfate minerals were found in this assemblage (scordariite, magnanelliite, and giacovazzoite [23-25]), along with all the other currently known species in the $\mathrm{K}_{2} \mathrm{O}-\mathrm{Fe}_{2} \mathrm{O}_{3}$ $\mathrm{SO}_{3}-\mathrm{H}_{2} \mathrm{O}$ system, with the only exception being represented by yavapaiite not yet identified at this locality:

(2) The occurrence of the uncommon fluo-sulfate khademite [26];

(3) The presence of outstanding specimens of coquimbite, observed in pseudohexagonal crystals up to $3 \mathrm{~cm}$ across [27], and voltaite [16].

The pyrite outcrop shows the pervasive growth of a complex assemblage of hydrated (Fe-Al-K)-bearing sulfates. One- to five-centimeter-thick veins of melanterite + halotrichite + alum-(K) \pm alunogen pervade the surface of the pyrite ore body (Figure 2a). As described by Biagioni et al. [16], a zoning in the sulfate assemblage can be observed. Indeed, two small trenches (about $1 \mathrm{~m}$ by width $\times 0.5 \mathrm{~m} \times 0.5 \mathrm{~m}$ in size) allowed a better description of the sulfate associations. In the inner portion of the ore body, masses of römerite associated to halotrichite, krausite, and coquimbite were observed (Figure 2b). In an intermediate zone between the external surface and the inner portion, abundant crystals of voltaite, along with römerite, goldichite, halotrichite, and melanterite (Figure 2c,d) were collected. Based on crystal size, rarity, and admixture with other phases, this study was focused on ten species. 

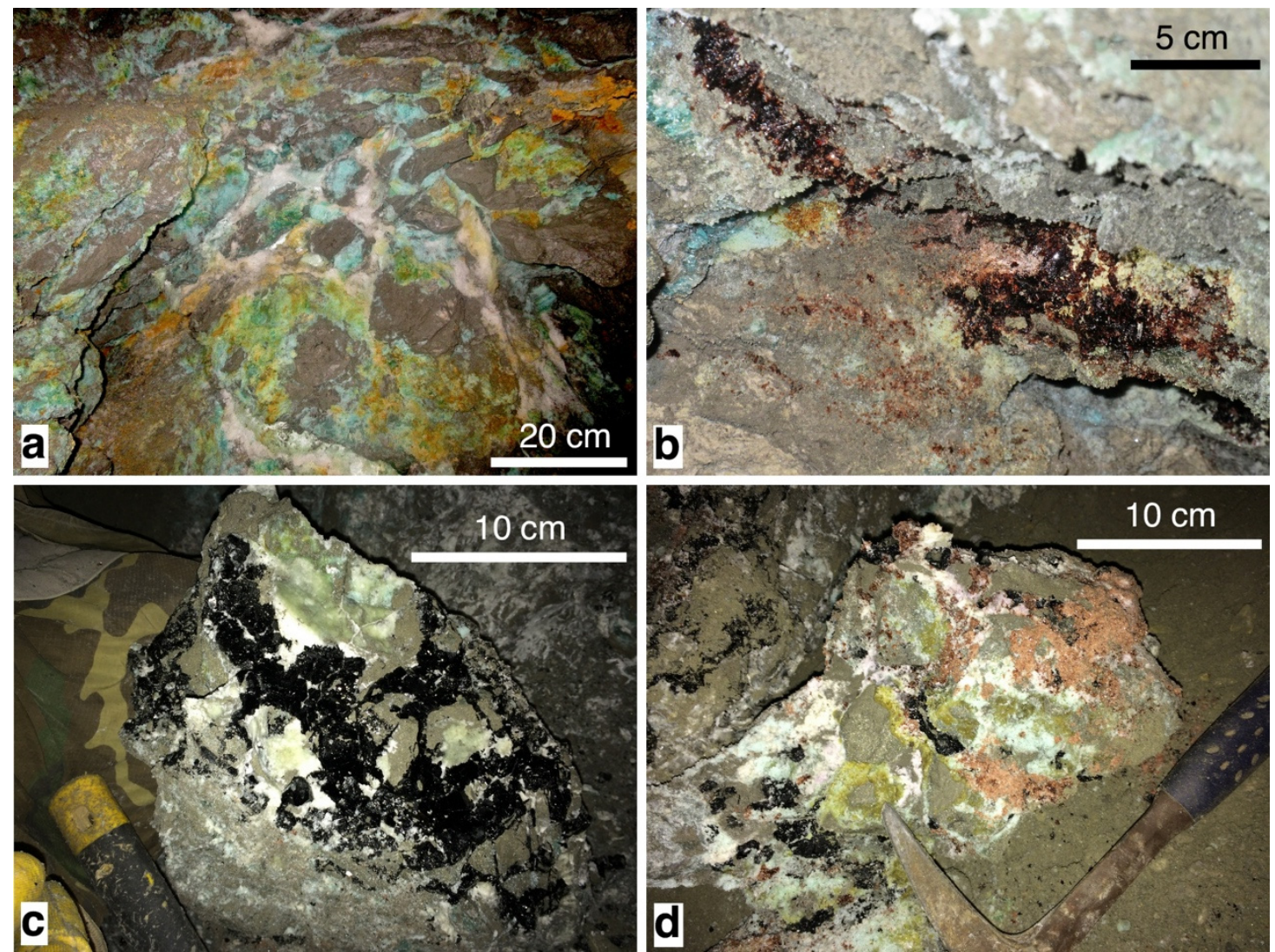

Figure 2. The sulfate occurrence of the Monte Arsiccio mine. (a) Melanterite (green-blue) with halotrichite + alunogen (white) and jarosite (yellow); (b) masses of well-crystallized römerite (brown); (c) boulder of pyrite ore (gold-gray) enclosing well-crystallized voltaite (black) and halotrichite (white and light green); (d) boulder of pyrite ore (gold-gray) encrusted with voltaite (black), halotrichite + alunogen + alum-(K) (white), and römerite (brown).

\section{Experimental}

\subsection{Samples}

Table 1 shows the studied sulfates (in bold). A short description of the main physical features shown by these ten sulfate minerals is reported below; the selected samples are also shown in Figure 3.

Alum-(K) occurs as granoblastic colorless aggregates, formed by equant crystals, in some cases showing a rude octahedral morphology. Alunogen forms cleavable colorless masses, whereas the sample of coquimbite used in this work is represented by crystal fragments, purple to violet in color. Aggregates of prismatic crystals of purple goldichite were made available for this study. Halotrichite forms typical fibrous whitish aggregates, whereas the rare mineral khademite was observed as sugary aggregates of vitreous colorless crystals. The sample of krausite was represented by small clusters of tabular crystals, which were brownish greenish in color. Melanterite forms anhedral grains, which are light green in color, whereas fragments of euhedral crystals of römerite and voltaite were used for the study of these latter two minerals.

These phases were preliminarily identified on the basis of their physical properties; the identification was further confirmed through X-ray powder diffraction and micro-Raman spectroscopy. 


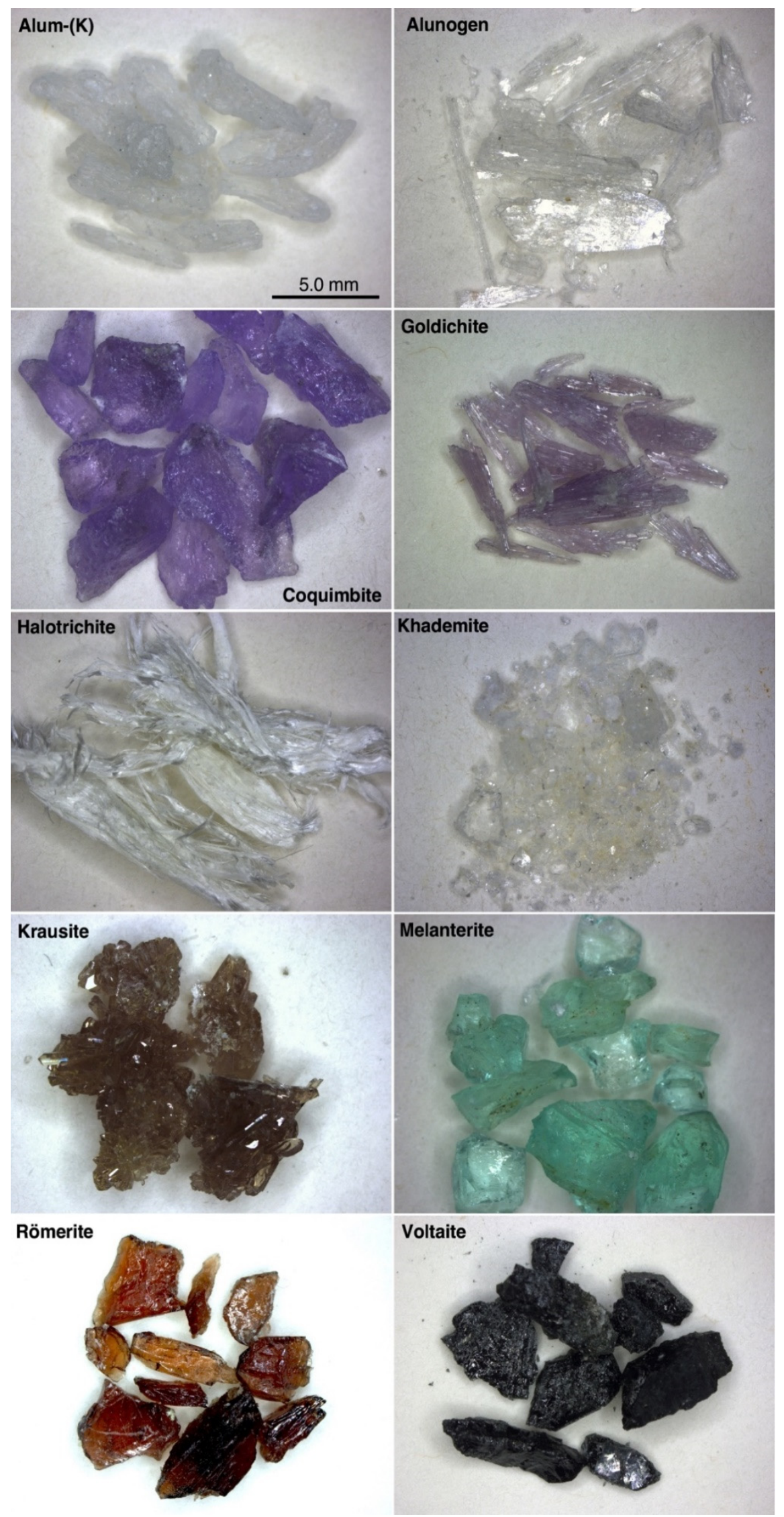

Figure 3. The sulfates used for this study. Purified aliquots of these samples were selected for the geochemical analyses. The pictures were all taken at the same magnification. 


\subsection{X-ray Diffraction and Micro-Raman Spectroscopy}

X-ray powder diffraction (XRPD) analyses were performed by using a Bruker D2 Phaser diffractometer $(30 \mathrm{kV}, 10 \mathrm{~mA})$, operating in Bragg-Brentano geometry $(\theta-\theta$ scan mode) and equipped with a one-dimensional Linxeye detector. Nickel-filtered $\mathrm{CuK \alpha}$ radiation was used. Data were collected in the scan range $5^{\circ}-65^{\circ}$ in $2 \theta$, with scan step of $0.02^{\circ}$ and counting time of $0.1 \mathrm{~s} / \mathrm{step}$.

Micro-Raman spectra were collected on un-oriented samples, using a Horiba JobinYvon XploRA Plus apparatus, with a $50 \times$ objective lens and the $532 \mathrm{~nm}$ line of a solid-state laser attenuated to $25 \%$ (i.e., $6.25 \mathrm{~mW}$ ). The spectra were collected in the range between 100 to $4000 \mathrm{~cm}^{-1}$, through multiple acquisitions (3), with counting times ranging between 60 and $120 \mathrm{~s}$. Backscattered radiation was analyzed with a $1200 \mathrm{~g} / \mathrm{mm}$ grating monochromator. Raman spectra were processed, using Fityk [28], subtracting the background and fitting the spectra to theoretical peak shapes, using Voigt functions. Experimental precision can be estimated at $\pm 2 \mathrm{~cm}^{-1}$.

Both analyses (XRPD and micro-Raman) were performed at the Pisa University's Dipartimento di Scienze della Terra.

\subsection{Inductively Coupled Plasma Mass Spectrometry}

The dissolution of each sulfate was performed by dissolving about $50 \mathrm{mg}$ of sample in $50 \mathrm{~mL}$ of $2 \% \mathrm{v} / \mathrm{v} \mathrm{HNO}_{3}$. Ultrapure water (Milli-Q, $>18.2 \mathrm{M} \Omega \cdot \mathrm{cm}$ ) and SupraPur $\mathrm{HNO}_{3}$ (Romil SuperPure) were used for sample preparation. After appropriate dilution with ultrapure water, the sample solutions were analyzed for the elements $\mathrm{Ag}, \mathrm{As}, \mathrm{Cd}, \mathrm{Co}$, $\mathrm{Cr}, \mathrm{Cs}, \mathrm{Cu}, \mathrm{Li}, \mathrm{Mo}, \mathrm{Ni}, \mathrm{Pb}, \mathrm{Rb}, \mathrm{Sb}, \mathrm{Sr}, \mathrm{Tl}, \mathrm{V}, \mathrm{U}$, and $\mathrm{Zn}$ with a Perkin Elmer NexION 300X inductively coupled plasma-mass spectrometer (ICP-MS) at the Pisa University's Dipartimento di Scienze della Terra. A solution containing $20 \mathrm{ng} / \mathrm{mL}$ of $\mathrm{Rh}$, Re, and Bi (internal standards) was mixed on-line, with the sample solution, just before reaching the nebulizer. The instrument was calibrated with synthetic solutions made by diluting and mixing $10 \mu \mathrm{g} / \mathrm{mL}$ single element stock solutions (Inorganic Ventures). Analyte masses and detection limits are reported in Table 2.

Table 2. Analytical isotopes and detection limits ( $\mu \mathrm{g} / \mathrm{g}$ in the solid sample) for ICP-MS analyses.

\begin{tabular}{ccc}
\hline Element & Analyte Isotope & Detection Limit \\
\hline- & (mass number) & $(\mu \mathrm{g} / \mathrm{g})$ \\
$\mathrm{Li}$ & 7 & 0.5 \\
$\mathrm{~V}$ & 51 & 1 \\
$\mathrm{Cr}$ & 53 & 1 \\
$\mathrm{Co}$ & 59 & 0.1 \\
$\mathrm{Ni}$ & 60 & 0.5 \\
$\mathrm{Cu}$ & 63 & 1 \\
$\mathrm{Zn}$ & 66 & 1 \\
$\mathrm{As}$ & 75 & 0.5 \\
$\mathrm{Rb}$ & 85 & 0.5 \\
$\mathrm{Sr}$ & 86 & 1 \\
$\mathrm{Mo}$ & 98 & 0.5 \\
$\mathrm{Ag}$ & 107 & 0.1 \\
$\mathrm{Cd}$ & 111 & 0.1 \\
$\mathrm{Sb}$ & 121 & 0.5 \\
$\mathrm{Cs}$ & 133 & 0.05 \\
$\mathrm{Tl}$ & 205 & 0.05 \\
$\mathrm{~Pb}$ & $206,207,208$ & 0.5 \\
$\mathrm{U}$ & 238 & 0.05 \\
$\mathrm{Rh}$ & 103 & \\
$\mathrm{Re}$ & 187 & \\
$\mathrm{Bi}$ & 209 & \\
\hline
\end{tabular}




\subsection{Dissolution Experiments}

For the mineral dissolution experiments, hand-picked grains of the studied sulfates were grinded in an agate mortar and pestle, to $<50 \mu \mathrm{m}$. For each mineral, $15.0 \mathrm{~g}$ of powders ( $7.5 \mathrm{~g}$ for alum-(K), alunogen, and goldichite, owing to the lack of more abundant pure material) was added to $75 \mathrm{~mL}$ of ultrapure water (Milli-Q, $>18.2 \mathrm{M} \Omega \cdot \mathrm{cm}$ ), in $100 \mathrm{~mL}$ glass beakers, set atop a stirring plate with a small Teflon stir bar. A flat piece of Styrofoam was placed between the base of the beaker and the stirring plate, to minimize the transfer of heat to the solutions. The $\mathrm{pH}$ and temperature of the solutions were monitored during the experiment. The $\mathrm{pH}$ electrode was calibrated at the beginning of each run, using a three-point $\mathrm{pH}$ buffer $(\mathrm{pH}=1.67,4.00$, and 7.00$)$, and the $\mathrm{pH}$ reading was corrected for temperature (Eutech Instruments $\mathrm{pH} /$ Ion 510 bench $\mathrm{pH}$-meter coupled with Hamilton/Polilyte Lab 238403 electrode). All dissolutions were conducted at room temperature, which varied from 25 to $28^{\circ} \mathrm{C}$. The concentration of ferric iron in alunogen, halotrichite, alum-(K), and melanterite was determined by iodometry. Five grams of each mineral was dissolved in $50 \mathrm{~mL}$ of $1 \mathrm{M} \mathrm{H}_{2} \mathrm{SO}_{4}$. Five milliliters of sample solution was treated with a $50 \% \mathrm{~m} / \mathrm{v}$ solution of potassium iodide (KI). Ferric iron is reduced to ferrous iron by iodide producing iodine according to the following reaction:

$$
2 \mathrm{Fe}^{3+}+2 \mathrm{I}^{-}=\mathrm{I}_{2}+2 \mathrm{Fe}^{2+}
$$

Iodine dissolves into the iodide-containing solution, giving triiodide ions $\left(\mathrm{I}_{3}{ }^{-}\right)$, which change the color solution to brown. The triiodide ion solution is then titrated against a $0.1 \mathrm{M}$ sodium thiosulfate $\left(\mathrm{Na}_{2} \mathrm{~S}_{2} \mathrm{O}_{3}\right)$ :

$$
\mathrm{I}_{3}{ }^{-}+2 \mathrm{~S}_{2} \mathrm{O}_{3}{ }^{-}=3 \mathrm{I}^{-}+\mathrm{S}_{4} \mathrm{O}_{6}{ }^{2-}
$$

The end-point is revealed by the addition of some drops of starch solution. The detection limit of the used method is about $0.1 \mathrm{wt} \% \mathrm{Fe}^{3+}$ in the solid sample.

\section{Results}

\subsection{Mineralogy of the Studied Samples}

Biagioni et al. [16] reviewed the main crystal-chemical features of the sulfates identified in the Monte Arsiccio assemblage. X-ray diffraction patterns confirmed that the selected samples used in this study were monophasic, within the detection limits of the XRPD (ca. $<1 \mathrm{wt} \%$ ). The identification was supported also by micro-Raman spectroscopy. Figure 4 shows the micro-Raman spectra of the studied phases. On the basis of their main structural features, the studied sulfates can be grouped into five groups, according to Hawthorne et al. [29]:

(1) Sulfates characterized by unconnected $\mathrm{SO}_{4}$ tetrahedra: alum-(K), alunogen, khademite, and melanterite (Figure $4 a, b)$;

(2) Sulfates with finite clusters of polyhedra: coquimbite, halotrichite, and römerite (Figure 4c,d);

(3) Sulfates with infinite chains: krausite (Figure 4e,f);

(4) Sulfates with infinite sheets: goldichite (Figure 4e,f);

(5) Sulfates with three-dimensional framework: voltaite (Figure 4e,f).

Raman bands and their interpretation are given in Table 3. The interpretations are based on previous studies [26,27,30-39]. It is worth noting that the Raman spectra of goldichite and krausite have not been previously reported in the literature. 

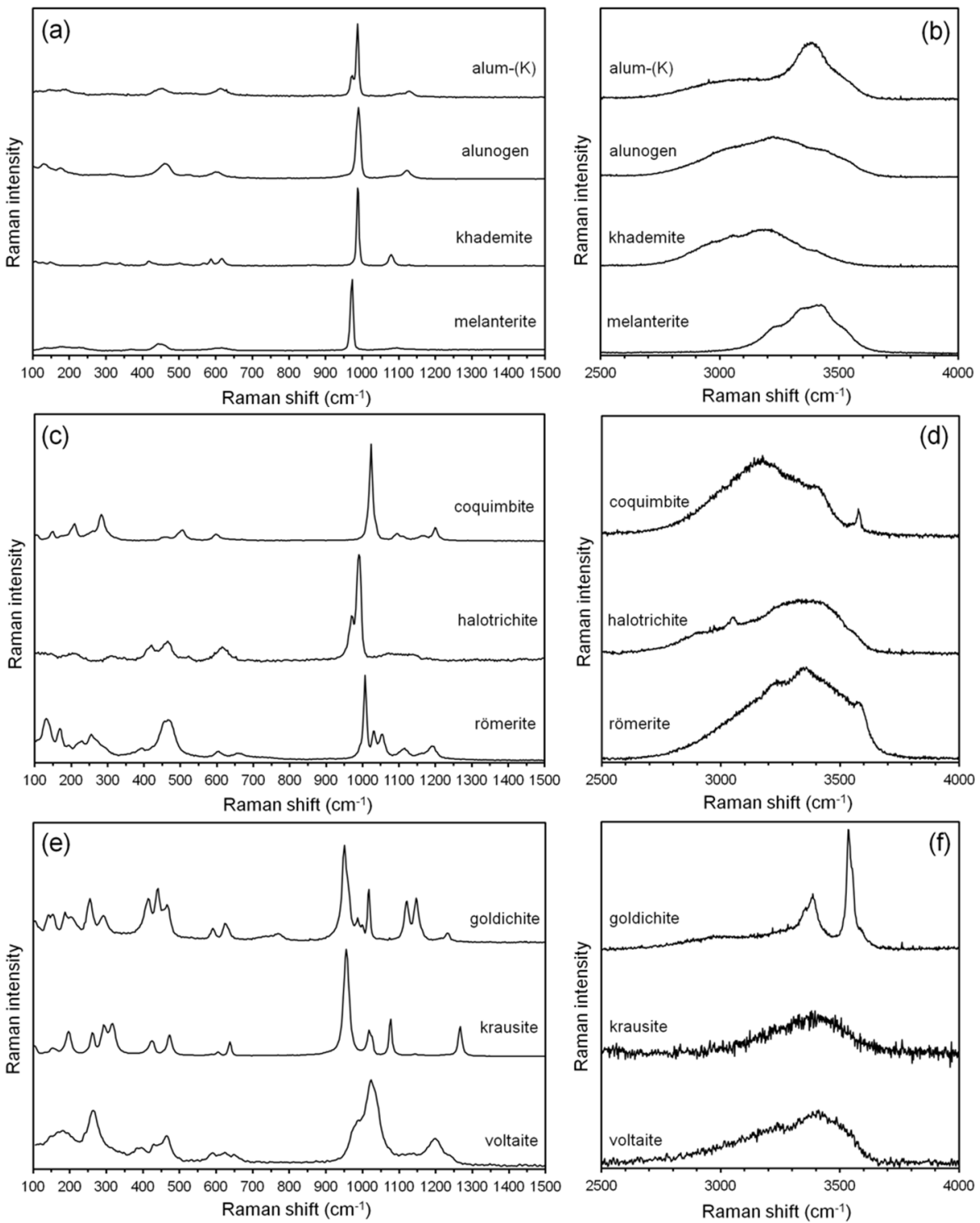

Figure 4. Raman spectra of the studied sulfates in the region between 100 and $1500 \mathrm{~cm}^{-1}$ and between 2500 and $4000 \mathrm{~cm}^{-1}$. (a,b) Alum-(K), alunogen, khademite, and melanterite; (c,d) coquimbite, halotrichite, and römerite; (e,f) goldichite, krausite, and voltaite.

Table 3. Raman bands (in $\mathrm{cm}^{-1}$ ) and their assignments for the studied sulfates.

\begin{tabular}{|c|c|c|c|c|c|c|}
\hline Mineral & $\begin{array}{c}\text { Me-O and } \\
\text { Lattice Modes }\end{array}$ & $v_{2}\left(\mathrm{SO}_{4}\right)$ & $v_{4}\left(\mathrm{SO}_{4}\right)$ & $v_{1}\left(\mathrm{SO}_{4}\right)$ & $v_{3}\left(\mathrm{SO}_{4}\right)$ & $v\left(\mathrm{H}_{2} \mathrm{O}\right)$ \\
\hline Alum-(K) & $146,188,313$ & 450,515 & 614 & 972,987 & 1102,1130 & $\begin{array}{c}2916,3139,3382, \\
3526\end{array}$ \\
\hline Alunogen & $\begin{array}{c}133,177,280 \\
319\end{array}$ & 459,524 & 602 & 990 & 1087,1123 & $\begin{array}{c}2979,3241,3441 \\
3526\end{array}$ \\
\hline Coquimbite & $148,208,281$ & 457,504 & 598 & 1024 & $1095,1164,1200$ & $\begin{array}{c}2944,3180,3405 \\
3577\end{array}$ \\
\hline Goldichite & $\begin{array}{l}141,155,186, \\
203,255,291\end{array}$ & $414,441,467$ & $\begin{array}{c}591,623,632, \\
741,771\end{array}$ & 951,990 & $\begin{array}{c}1017,1120,1147 \\
1232\end{array}$ & $\begin{array}{c}1637,3009,3328 \\
3382,3536,3553, \\
3558\end{array}$ \\
\hline
\end{tabular}


Table 3. Cont

\begin{tabular}{|c|c|c|c|c|c|c|}
\hline Mineral & $\begin{array}{c}\text { Me-O and } \\
\text { Lattice Modes }\end{array}$ & $v_{2}\left(\mathrm{SO}_{4}\right)$ & $v_{4}\left(\mathrm{SO}_{4}\right)$ & $v_{1}\left(\mathrm{SO}_{4}\right)$ & $v_{3}\left(\mathrm{SO}_{4}\right)$ & $v\left(\mathrm{H}_{2} \mathrm{O}\right)$ \\
\hline Halotrichite & $212,316,350$ & 423,468 & 620 & 975,995 & $1075,1102,1141$ & $\begin{array}{c}2895,3049,3264, \\
3423\end{array}$ \\
\hline Khademite & $\begin{array}{l}127,150,300 \\
337\end{array}$ & $\begin{array}{l}417,432,500 \\
514\end{array}$ & $\begin{array}{c}567,587,602, \\
617\end{array}$ & 987 & 1079,1129 & $\begin{array}{c}2965,3049,3197, \\
3405\end{array}$ \\
\hline Krausite & $\begin{array}{c}142,196,259 \\
291,315\end{array}$ & $422,456,472$ & 635 & $\begin{array}{c}953,983,1016 \\
1076\end{array}$ & $1141,1219,1265$ & 3390 \\
\hline Melanterite & $\begin{array}{l}140,197,243, \\
381\end{array}$ & 447 & 607 & 980 & 1101,1142 & $\begin{array}{c}1655,3243,3335 \\
3427,3521\end{array}$ \\
\hline Römerite & $\begin{array}{l}138,173,230 \\
260\end{array}$ & 463 & 608,665 & 1011,1036 & $\begin{array}{c}1058,1117,1166 \\
1196\end{array}$ & $\begin{array}{c}1653,3249,3352, \\
3486\end{array}$ \\
\hline Voltaite & $179,263,392$ & $433,464,589$ & 621,650 & 988,1025 & 1200,1240 & 3204,3437 \\
\hline
\end{tabular}

Note: libration modes are shown in italic.

\subsection{Trace-Element Content in Sulfate Minerals}

The results of ICP-MS analyses of the studied sulfates are reported in Table 4. In general, the concentrations of the determined elements are relatively low and, in many cases, below the detection limit of the used method. The most interesting exceptions are the following (Figure 5):

(1) $\mathrm{Tl}(1370-2988 \mu \mathrm{g} / \mathrm{g})$ and $\mathrm{Rb}(140-252 \mu \mathrm{g} / \mathrm{g})$ in the four K-bearing sulfates alum-(K), goldichite, krausite, and voltaite;

(2) As (505-1680 $\mu \mathrm{g} / \mathrm{g})$ in coquimbite, goldichite, krausite, and voltaite;

(3) $\mathrm{Sb}(41-81 \mu \mathrm{g} / \mathrm{g})$ in khademite and voltaite;

(4) $\mathrm{Co}, \mathrm{Ni}, \mathrm{Cu}$ and $\mathrm{Zn}$ in melanterite; $\mathrm{Co}, \mathrm{Ni}$, and $\mathrm{Zn}$ in römerite;

(5) $\mathrm{Cr}(14-65 \mu \mathrm{g} / \mathrm{g})$ in alum-(K), alunogen, coquimbite, halotrichite, and khademite.

Table 4. ICP-MS analyses (in $\mu \mathrm{g} / \mathrm{g}$ ) of the studied sulfates.

\begin{tabular}{|c|c|c|c|c|c|c|c|c|c|c|}
\hline & Alum-(K) & Alunogen & Coquimbite & Goldichite & Halotrichite & Khademite & Krausite & Melanterite & Römerite & Voltaite \\
\hline $\mathrm{Li}$ & $<0.5$ & $<0.5$ & $<0.5$ & $<0.5$ & $<0.5$ & 3.0 & 3.8 & $<0.5$ & $<0.5$ & 3.8 \\
\hline $\mathrm{V}$ & $<1$ & $<1$ & 1 & 20 & $<1$ & 4 & 16 & $<1$ & 5 & 42 \\
\hline $\mathrm{Cr}$ & 31 & 65 & 21 & $<1$ & 52 & 14 & $<1$ & $<1$ & 7 & $<1$ \\
\hline Co & $<0.1$ & $<0.1$ & $<0.1$ & $<0.1$ & 2.2 & $<0.1$ & $<0.1$ & 15.8 & 10.5 & 6.8 \\
\hline $\mathrm{Ni}$ & $<0.5$ & $<0.5$ & $<0.5$ & $<0.5$ & 9.6 & $<0.5$ & $<0.5$ & 66 & 30.0 & 8.4 \\
\hline $\mathrm{Cu}$ & $<1$ & $<1$ & $<1$ & 6 & $<1$ & $<1$ & 4 & 72 & 12 & 18 \\
\hline $\mathrm{Zn}$ & $<1$ & $<1$ & $<1$ & 8 & 39 & $<1$ & 15 & 47 & 64 & 230 \\
\hline As & 10.4 & 1.4 & 1531 & 1094 & 12.3 & 5.8 & 1680 & $<0.5$ & 2.0 & 505 \\
\hline $\mathrm{Rb}$ & 140 & $<0.5$ & $<0.5$ & 252 & $<0.5$ & 1.4 & 236 & $<0.5$ & $<0.5$ & 140 \\
\hline $\mathrm{Sr}$ & $<1$ & $<1$ & $<1$ & $<1$ & $<1$ & $<1$ & $<1$ & $<1$ & $<1$ & $<1$ \\
\hline Mo & $<0.5$ & $<0.5$ & $<0.5$ & $<0.5$ & $<0.5$ & $<0.5$ & $<0.5$ & $<0.5$ & $<0.5$ & $<0.5$ \\
\hline $\mathrm{Ag}$ & 0.6 & $<0.1$ & $<0.1$ & $<0.1$ & 0.2 & $<0.1$ & 0.4 & $<0.1$ & $<0.1$ & $<0.1$ \\
\hline $\mathrm{Cd}$ & $<0.1$ & $<0.1$ & $<0.1$ & $<0.1$ & 0.2 & $<0.1$ & 0.2 & $<0.1$ & $<0.1$ & 2.1 \\
\hline $\mathrm{Sb}$ & 10.7 & $<0.5$ & 3.0 & 9.4 & 2.3 & 81 & 6.5 & 0.6 & $<0.5$ & 41 \\
\hline Cs & 4.5 & $<0.05$ & $<0.05$ & $<0.05$ & $<0.05$ & $<0.05$ & $<0.05$ & $<0.05$ & $<0.05$ & 0.36 \\
\hline $\mathrm{Tl}$ & 2501 & 3.5 & 3.9 & 1541 & 2.77 & 10.9 & 1370 & 0.92 & 6.8 & 2988 \\
\hline $\mathrm{Pb}$ & 14.3 & $<0.5$ & $<0.5$ & $<0.5$ & $<0.5$ & 0.7 & $<0.5$ & $<0.5$ & $<0.5$ & $<0.5$ \\
\hline $\mathrm{U}$ & $<0.05$ & $<0.05$ & $<0.05$ & $<0.05$ & $<0.05$ & $<0.05$ & $<0.05$ & $<0.05$ & $<0.05$ & 1.83 \\
\hline
\end{tabular}




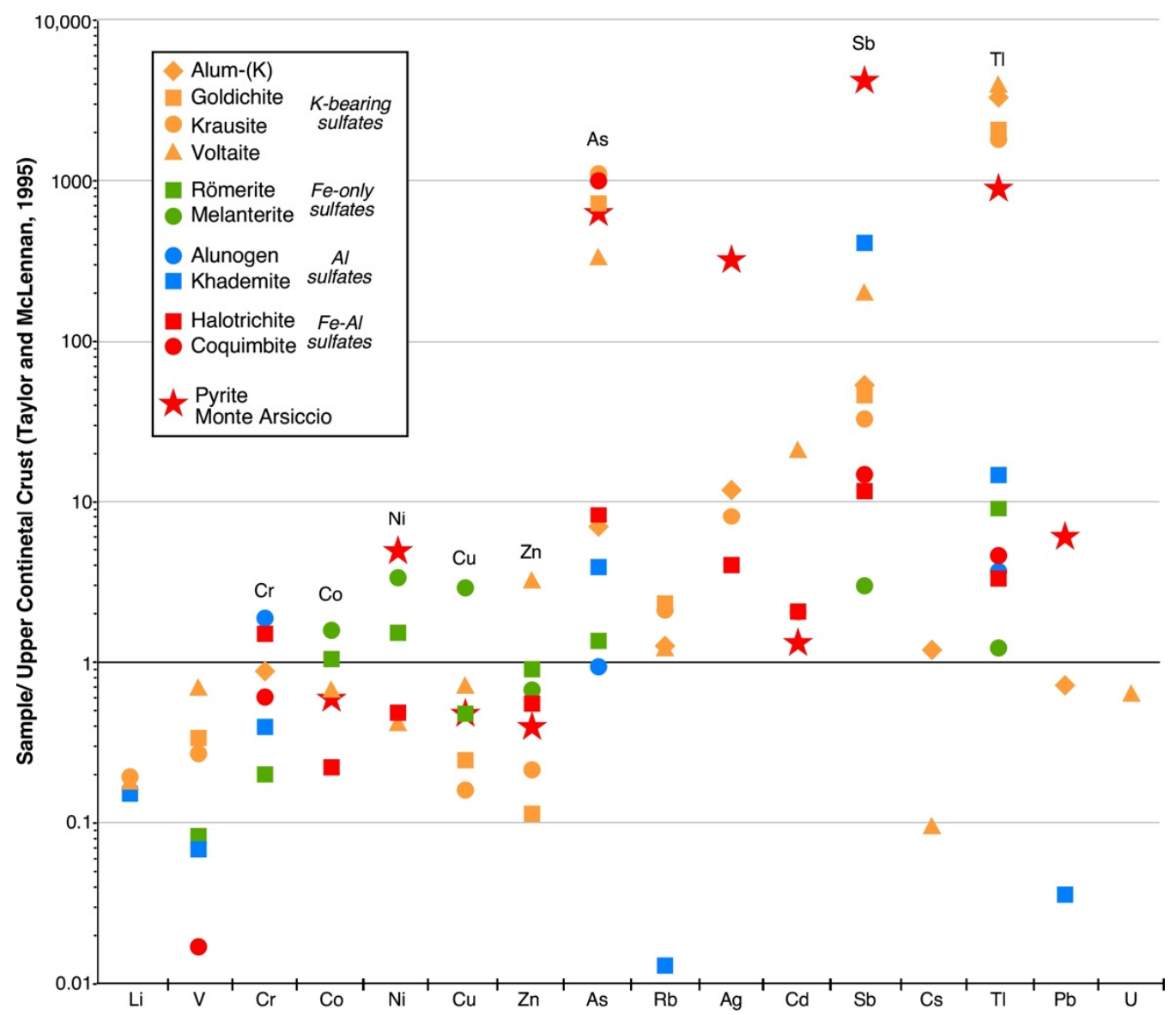

Figure 5. Concentrations of trace elements in the studied sulfates normalized to the Upper Continental Crust values of Taylor and McLennan [40]. Red stars represent the average values of 135 spot analyses by LA-ICP-MS of the Monte Arsiccio pyrite, taken from George et al. [9].

\subsection{Dissolution Experiments}

The results of the mineral dissolution experiments are shown in Figure 6, which reports the $\mathrm{pH}$ value vs. elapsed time. All experiments showed a significant decrease of $\mathrm{pH}$ during the first $30 \mathrm{~s}$ from the beginning of the dissolution (Figure 6a). This decrease (measured from the $\mathrm{pH}$ of the Milli-Q water) varied from $2.44 \mathrm{pH}$ units for melanterite to $3.67 \mathrm{pH}$ units for römerite. After $120 \mathrm{~min}$, the $\mathrm{pH}$ of the solutions stabilized around a nearly constant value. Halotrichite and melanterite, iron sulfates nominally containing $\mathrm{Fe}^{2+}$ and no $\mathrm{Fe}^{3+}$, dissolved, completely giving a final solution with $\mathrm{pH}$ of 2.18 and 3.04, respectively. Frau [17] obtained very similar results dissolving melanterite (from the Genna Luas mine, Sardinia, Italy) and its synthetic analogue at a concentration of $200 \mathrm{~g} / \mathrm{L}$. Valente and Gomes [18] dissolved halotrichite and melanterite + rozenite from the Valdarcas mine (Portugal), at a concentration of $20 \mathrm{~g} / \mathrm{L}$ obtaining $\mathrm{pH}$ values of $\sim 3.3$ and 3.6, respectively. Alunogen and alum-K) dissolved completely, giving a final solution with $\mathrm{pH}$ of 2.53 and 2.89 , respectively. Coquimbite, goldichite, and krausite, sulfates nominally containing just $\mathrm{Fe}^{3+}$ and no $\mathrm{Fe}^{2+}$, dissolved only partially, giving a final solution with a $\mathrm{pH}$ of 1.41, 1.87, and 1.91, respectively. Römerite and voltaite, sulfates containing both $\mathrm{Fe}^{2+}$ and $\mathrm{Fe}^{3+}$, dissolved completely, giving a final solution with $\mathrm{pH}$ of 1.28 and 1.56, respectively.

A single experiment aimed at evaluating the effect of increasing the mass of dissolved sulfate on the solution acidity was performed by using römerite. The results (Figure $6 \mathrm{~b}$ ) indicate a regular decrease of $\mathrm{pH}$ increasing the amount of dissolved römerite down to $\mathrm{pH}=0.86$, at a dissolved römerite concentration of $36.7 \% \mathrm{~m} / \mathrm{m}(43.6 \mathrm{~g}$ römerite $+75.0 \mathrm{~g}$ water). At the end of this experiment, the solution was still undersaturated with römerite. 

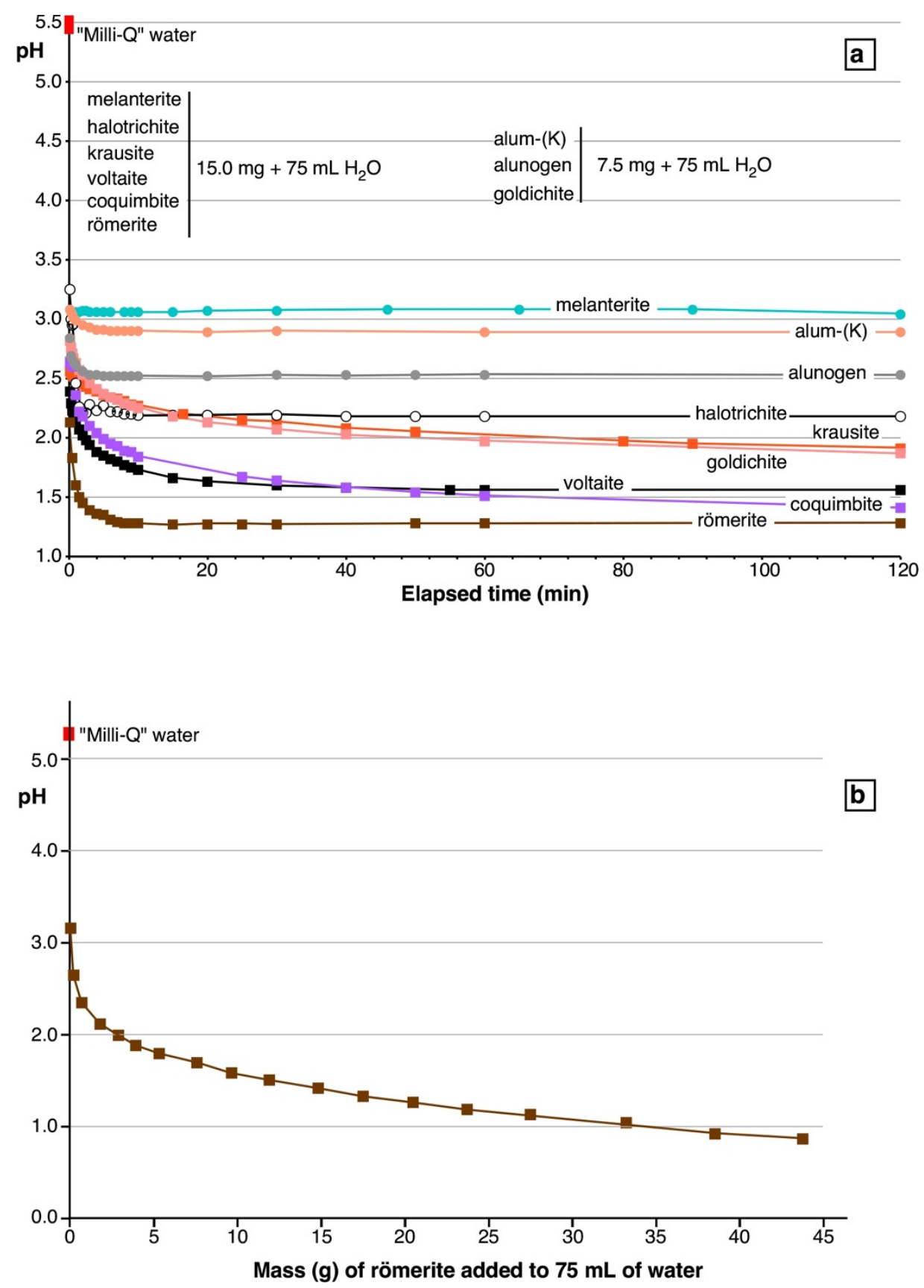

Figure 6. Relationships between measured $\mathrm{pH}$ and elapsed times in the dissolution experiments of the studied sulfates (a). In (b), the $\mathrm{pH}$ variation as a function of the dissolved mass of römerite is shown.

\section{Discussion}

6.1. From Geochemistry to Crystal-Chemistry: The Role of Sulfate Minerals in Sequestering PTE

Trace-element contents, as revealed by ICP-MS analyses, can be related both to the geochemistry of pyrite ores and their host rocks and to the crystal-chemistry of crystallizing sulfates. Since the exploratory study of Biagioni et al. [7], further geochemical investigations [8,9] have shown the main features of the Monte Arsiccio pyrite ores. In particular, as indicated in Figure 5, taking into account the average trace-element budget of pyrite, several elements are more abundant than in average crustal rocks: $\mathrm{Ni}, \mathrm{As}, \mathrm{Mo}, \mathrm{Ag}, \mathrm{Cd}$, $\mathrm{Sb}, \mathrm{Tl}$, and $\mathrm{Pb}$. These geochemical features are mirrored by the trace-element contents measured in sulfates. In addition, the composition of these latter phases is also influenced by the geochemistry of host rocks. No data are available for the Monte Arsiccio mine; 
however, Vezzoni et al. [41] reported major- and trace-element contents in the Paleozoic formations cropping out in the Sant'Anna tectonic window, where the Monte Arsiccio mine is located. In particular, the host rocks are strongly enriched in K, resulting in the relatively high abundance of K-sulfates in the studied assemblage.

In these minerals, $\mathrm{K}$ can be easily replaced by $\mathrm{Tl}$ and $\mathrm{Rb}$, owing to the similar ionic radii and the same formal charge. Indeed, alum-(K), goldichite, krausite, and voltaite are enriched in both these trace elements. The substitution of $\mathrm{K}$ by $\mathrm{Tl}$ was previously described by Biagioni et al. [31], in alum-(K) and voltaite from the Fornovolasco mine, where this substitution is even more pronounced, reaching some $\mathrm{wt} \%$ in both sulfates. This is likely related to the higher $\mathrm{Tl}$ content shown by pyrite ores at Fornovolasco [7-9]. High Tl and $\mathrm{Rb}$ concentrations (377-1646 and 53-182 $\mathrm{\mu g} / \mathrm{g}$, respectively) were also found by Dimitrova et al. [4], in the voltaite efflorescences formed by oxidation at laboratory conditions of colloform pyrite (Chiprovtsi deposit, Bulgaria). While the high Tl contents in K-sulfates can be explained on the basis of crystal-chemical considerations, the values measured in the other phases are more difficult to be explained. Actually, these values are two to three orders of magnitude lower than those observed in K-sulfates. The higher contents were measured in khademite $(10.9 \mu \mathrm{g} / \mathrm{g})$ and römerite $(6.8 \mu \mathrm{g} / \mathrm{g})$. The crystal structure of both minerals does not show any site potentially able to host the large monovalent $\mathrm{Tl}^{+}$cation; on the contrary, they could potentially be able to host the smaller and high-charged $\mathrm{Tl}^{3+}$ cation, but no data suggesting the oxidation of $\mathrm{Tl}$ from the monovalent to the trivalent state in the studied assemblage are currently available. In addition, taking into account the crystallization sequence observed at Monte Arsiccio [16], this explanation seems unlikely, because römerite is among the first formed phases. Another hypothesis could be related to the widespread occurrence of fluid inclusions observed in both khademite and römerite. Thallium is likely preferentially partitioned in the aqueous fluid and can enter in the crystal structure of crystallizing sulfates only late in the crystallization process. Finally, taking into account the analytical technique employed for the trace-element analysis, a contamination by other phases occurring as $\mu \mathrm{m}$-sized inclusions, cannot be completely ruled out.

Arsenic is enriched in coquimbite, krausite, goldichite, and voltaite. It is very likely that As enters the crystal structure of these species as $\mathrm{As}^{5+}$, replacing $\mathrm{S}^{6+}$. The substitution mechanism is not yet clear. Indeed, it could involve the heterovalent double substitution $\mathrm{S}^{6+}+\mathrm{O}^{2-}=\mathrm{As}^{5+}+\mathrm{OH}^{-}$, with the protonation of one oxygen atom belonging to the coordination tetrahedron centered by As, or through some kinds of heterovalent substitution involving other cation sites. The As-enriched nature of coquimbite has been reported from other occurrences. For instance, Romero et al. [42] observed a relation between the modal abundance of coquimbite and the As content of the sulfates from the abandoned mine site of La Peña del Hierro, in the Iberian Pyrite Belt, Spain; similarly, Nieva et al. [43] reported high As concentrations in sulfate efflorescences from the abandoned tailing dams at La Concordia mine, Argentina, with copiapite and coquimbite as the dominant crystalline phases. Halotrichite, khademite, römerite, and alunogen have a definitely lower, but still detectable, As content. Extremely high As contents (417-16,600 $\mu \mathrm{g} / \mathrm{g}$ ) were measured in efflorescent voltaite, halotrichite, and römerite grown on the arsenian colloform pyrite from the Chiprovtsi deposit, Bulgaria [4].

Antimony is another PTE enriched in the Monte Arsiccio assemblage, likely as $\mathrm{Sb}^{5+}$ cation. It is particularly concentrated in khademite $(81 \mu \mathrm{g} / \mathrm{g})$ and voltaite $(41 \mu \mathrm{g} / \mathrm{g})$, but there is not a clear crystal-chemical mechanism allowing an explanation for this preferential partitioning.

On the contrary, the contents of $\mathrm{Co}, \mathrm{Ni}, \mathrm{Cu}$, and $\mathrm{Zn}$ detected in melanterite, as well as those of $\mathrm{Co}, \mathrm{Ni}$, and $\mathrm{Zn}$ measured in römerite are easily explained on the basis of a simple homovalent substitution between $\mathrm{Fe}^{2+}$ and the other divalent transition metals. In the melanterite group, species having Co (bieberite), $\mathrm{Cu}$ (boothite), and $\mathrm{Zn}$ (zinc-melanterite) as dominant divalent cation are known [3]. Currently, no Ni-dominant analogues of melanterite are known. Indeed, the maximum $\mathrm{Ni}$ content corresponds to the formula $\left(\mathrm{Fe}_{0.54} \mathrm{Ni}_{0.46}\right) \mathrm{SO}_{4} \cdot 7 \mathrm{H}_{2} \mathrm{O}$ [3], whereas natural occurrences showed lower $\mathrm{Ni}$ contents [44]. 
Similar minor- to trace-elements contents in melanterite are commonly reported by other authors (e.g., $[19,20])$. Cobalt, $\mathrm{Ni}$, and $\mathrm{Zn}$ can replace $\mathrm{Fe}^{2+}$ in römerite; for instance, the $\mathrm{Zn}$ analogue of römerite is known as lishizhenite [45]. Zinc is enriched also in voltaite (along with minor $\mathrm{Cd}$, that likely follows the fate of $\mathrm{Zn}$, owing to their geochemical affinity); this is not surprising, taking into account the existence of the Zn-analogue of voltaite, zincovoltaite [46].

Chromium (most likely as $\mathrm{Cr}^{3+}$ ) is hosted in those phases characterized by $\mathrm{Al}^{3+}$. Indeed, it occurs in alunogen, halotrichite, alum-(K), coquimbite, and khademite. Chromiumanalogues of some of these phases are known, both natural and synthetic (e.g., [47,48]).

A last geochemical feature is represented by low amounts of $V$ (up to $42 \mu \mathrm{g} / \mathrm{g}$ ), likely in the trivalent state, occurring in goldichite, krausite, and voltaite. The V-rich nature of the Monte Arsiccio ore is known since the first identification of mannardite [49] and the subsequent finding of other $\mathrm{V}$ - or V-bearing phases (derbylite, graeserite, mapiquiroite, and stibivanite $[50,51])$.

\subsection{Sulfate Dissolution and Acidity Production}

The major metal ions occurring in the experimental solutions are $\mathrm{Fe}^{3+}, \mathrm{Al}^{3+}, \mathrm{Fe}^{2+}$, and $\mathrm{K}^{+}$. These positive ions attract, to variable extent, the electron cloud of their water of hydration, making their $\mathrm{OH}$ bond weaker and the water acidic, according to the following reaction:

$$
\mathrm{MOH}_{2}{ }^{\mathrm{n}+}+\mathrm{H}_{2} \mathrm{O}=\mathrm{MOH}^{(\mathrm{n}-1)+}+\mathrm{H}_{3} \mathrm{O}^{+}
$$

The $\mathrm{pKa}$ of $\mathrm{Fe}^{3+}, \mathrm{Al}^{3+}, \mathrm{Fe}^{2+}$, and $\mathrm{K}^{+}$at $25^{\circ} \mathrm{C}$ for the above reaction are 2.2, 5.0, 9.4, and 14.0, respectively [52]. The equilibrium constant for $\mathrm{K}^{+}$is very small; thus, this ion in a solution can induce just a minor change of water $\mathrm{pH}$. The equilibrium constant of equation for $\mathrm{Fe}^{3+}$ is $2.8 \log$ units larger than that of $\mathrm{Al}^{3+}$ and $7.2 \log$ units larger than that of $\mathrm{Fe}^{2+}$. Therefore, it could be expected that the acidity of the solutions of the sulfate minerals of this study will be mainly controlled by the concentration, even at low levels of $\mathrm{Fe}^{3+}$, and by the concentration of $\mathrm{Al}^{3+}$ in the Al-bearing phases. We determined the concentration of $\mathrm{Fe}^{3+}$ in alunogen, halotrichite, alum-(K), and melanterite (four sulfates not containing $\mathrm{Fe}^{3+}$ in their end-member formulae), finding $1.24,0.94,0.47$, and $0.13 \mathrm{wt} \% \mathrm{Fe}^{3+}$, respectively. These data thus confirm the conclusions by Hurowitz et al. [53] concerning the considerable effect of $\mathrm{Fe}^{3+}$, even when present as a minor component, on the acidity of mine waters.

\subsection{Sulfate Mineralogy and AMD Geochemistry}

As reported in the Introduction, the hydrogeological setting of the Monte Arsiccio mining area, coupled with the high rainfall of the Apuan Alps, favors an intense interaction between meteoric water and orebodies, promoting the formation of AMD. Acidic effluents come out from many adits of the Monte Arsiccio mine but are particularly abundant at the Sant'Erasmo tunnel [10]. Indeed, this is the lowest level (485 m a.m.s.l.) of the whole mining area collecting the majority of its internal waters. The geochemistry of the AMD flowing out of the Sant'Erasmo tunnel, along with other physicochemical parameters (e.g., temperature, $\mathrm{pH}$, Eh, electrical conductivity, flow rate, etc.), is well constrained [10,12]. In Figure 7, the maximum, minimum, and average concentration $(\mu \mathrm{g} / \mathrm{L})$ of a series of PTEs, measured over the period 2014-2016, in the AMD from the Sant'Erasmo tunnel, are reported, along with the concentration $(\mu \mathrm{g} / \mathrm{g})$ of the same elements in the studied sulfates. 


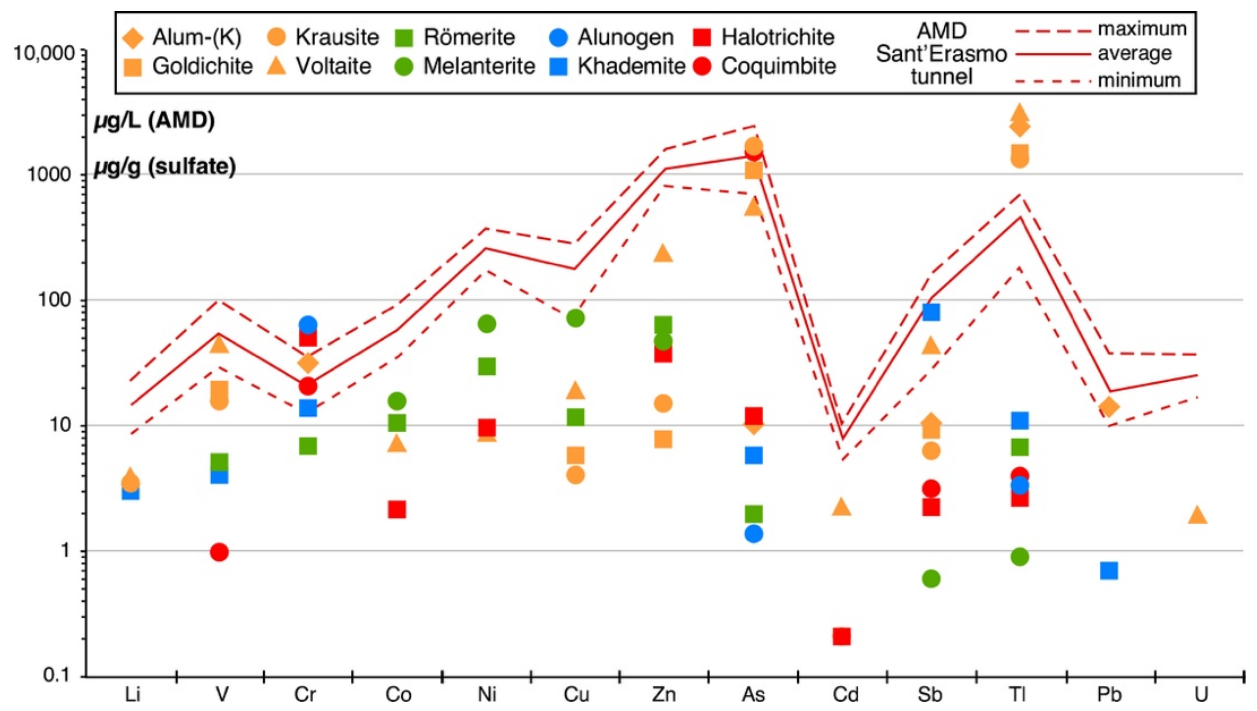

Figure 7. Concentrations (in $\mu \mathrm{g} / \mathrm{g}$ ) of trace elements in the studied sulfates, along with concentrations (in $\mu \mathrm{g} / \mathrm{L}$ ) of the same elements in the acid mine drainage (AMD) from the Sant'Erasmo tunnel (Monte Arsiccio mine). The AMD concentrations are taken from [12] and represent the maximum, minimum, and average values measured over the period 2014-2016.

According to Perotti et al. [10], the AMD at the Sant'Erasmo tunnel can be classified as a high-acid/high-metal type. As stressed by these authors, almost $99.3 \%$ of the total metal and metalloids occurring in mine waters is represented by $\mathrm{Fe}(98.3 \%)$ and $\mathrm{Al}(1.0 \%)$, i.e., the two most abundant chemical components of the sulfate assemblage from the Monte Arsiccio mine. Moreover, from Figure 7, it may be argued that sulfates exert a control over the concentrations of $\mathrm{Tl}, \mathrm{As}, \mathrm{Sb}$, and $\mathrm{Cr}$ in the studied $\mathrm{AMD}$. Even if only a qualitative comparison between trace-element contents in sulfates and in AMD can be proposed, it is interesting to observe that, whereas, in sulfate minerals, $\mathrm{Tl}$ content is comparable or even slightly larger than As content, in AMD, As is enriched with respect to $\mathrm{Tl}$, notwithstanding the well-known capacity of As to be adsorbed on Fe- and Al-oxy-hydroxides (e.g., [54]). This $\mathrm{Tl}$ depletion could be possibly related to the crystallization of Tl-bearing K-sulfates, in some cases showing low solubilities (e.g., krausite and goldichite). In this way, the sulfate assemblage of the Monte Arsiccio may play an active role as long-term sinks of $\mathrm{Tl}$ in the AMD system, similarly to what is suggested by Biagioni et al. [31] for the Fornovolasco mine, where Tl-bearing alum-(K) and voltaite have been observed. As a matter of fact, the occurrence of K-rich country rocks, favoring the crystallization of several kinds of $\mathrm{K}$-sulfates (not only those studied in this work but also alunite supergroup minerals such as jarosite), seems to be the main factor promoting the $\mathrm{Tl}$ sequestration. In addition to these geochemical features, also the $\mathrm{pH}$ value of the AMD from Sant'Erasmo tunnel $($ maximum $=2.50$, minimum $=1.46$, average $=2.00$ over the period 2014-2015 $[10,12])$ suggests it could be at least partially controlled by the dissolution of secondary sulfates, in agreement with the dissolution experiments carried out in this study.

\section{Conclusions}

This is a detailed mineralogical and geochemical study of an exceptional assemblage of well-crystallized hydrated (Fe-Al-K)-bearing sulfates from the Monte Arsiccio mine. Analytical data and dissolution experiments allowed us to draw the following conclusions in terms of partitioning of many PTE in the secondary sulfates and production of acid waters by sulfate dissolution:

1. The studied secondary sulfates show a widely variable ability to store PTE in accordance with their widely variable crystal-chemistry.

2. The four K-bearing sulfates store a significant quantity of $\mathrm{Tl}$ (and $\mathrm{Rb}$ ), whereas coquimbite, goldichite, krausite, and voltaite are a repository of As. The Al-rich sulfates 
alunogen, halotrichite, alum-(K), coquimbite, and khademite show an enrichment in $\mathrm{Cr}$. The Fe-only sulfates melanterite and römerite are characterized by a modest enrichment in the base metals $\mathrm{Cu}, \mathrm{Zn}, \mathrm{Co}$, and Ni. Finally, khademite and, less so, voltaite exhibit moderately high concentrations of $\mathrm{Sb}$.

3. Dissolution experiments demonstrate that the dissolution of the studied sulfates always produces acidity. The acidity is ultimately generated by $\mathrm{Fe}^{3+}$ hydrolysis. Even the secondary sulfates not containing $\mathrm{Fe}^{3+}$ in their ideal chemical formula (alum-(K), alunogen, halotrichite, and melanterite) generate acidity upon their dissolution in water due to the measured occurrence of minor amounts of $\mathrm{Fe}^{3+}$. The highly soluble secondary sulfates containing high proportions of $\mathrm{Fe}^{3+}$ (e.g., römerite, coquimbite, and voltaite) can easily induce a decrease of the $\mathrm{pH}$ of the solutions down to values $<1.0$.

4. The geochemistry of the AMD flowing out of the Monte Arsiccio mine is the result of a very complex series of processes occurring inside the mineralized area. However, the comparison between the PTE concentrations of the AMD and those measured in the studied secondary sulfates suggests that the dissolution of the latter may exert a strong control over the concentrations of dissolved $\mathrm{Tl}, \mathrm{As}, \mathrm{Sb}$, and $\mathrm{Cr}$.

\begin{abstract}
Author Contributions: Conceptualization, M.D. and D.M.; data curation, M.D., D.M. and M.V.; writing—original draft, M.D., D.M., M.V. and C.B. All authors have read and agreed to the published version of the manuscript.

Funding: This research was financially supported by the Ministero dell'Istruzione, Università e Ricerca through the project PRIN 2017 "TEOREM-deciphering geological processes using Terrestrial and Extraterrestrial ORE Minerals", grant number 2017AK8C32.
\end{abstract}

Acknowledgments: Two anonymous referees are thanked for their constructive reviews, and Chris Brown for editorial handling. Mario Bianchini is acknowledged for providing some of the studied samples.

Conflicts of Interest: The authors declare no conflict of interest.

\title{
References
}

1. Rimstidt, J.D.; Vaughan, D.J. Pyrite oxidation: A state-of-the-art assessment of the reaction mechanism. Geochim. Cosmochim. Acta 2003, 67, 873-880. [CrossRef]

2. Nordstrom, D.K.; Alpers, C.N. Negative pH, efflorescent mineralogy, and consequences for environmental restoration at the Iron Mountain Superfund site, California. Proc. Natl. Acad. Sci. USA 1999, 96, 3455-3462. [CrossRef] [PubMed]

3. Jambor, J.L.; Nordstrom, K.D.; Alpers, C.N. Metal-sulfates salts from sulfide minerals oxidation. In. Sulfate mineralscrystallography, geochemistry and environmental significance. Rev. Mineral. Geochem. 2000, 40, 305-340. [CrossRef]

4. Dimitrova, D.; Mladenova, V.; Hecht, L. Efflorescent sulfate crystallization on fractured and polished colloform pyrite surfaces: A migration pathway of trace elements. Minerals 2020, 10, 12. [CrossRef]

5. Cravotta, C.A., III. Secondary iron-sulfate minerals as sources of sulfate and acidity. In Environmental Geochemistry of Sulfide Oxidation; Alpers, C.N., Blowes, D.W., Eds.; American Chemical Society: Washington, DC, USA, 1994; pp. 345-364.

6. Williamson, M.A.; Rimstidt, J.D. The kinetics and electrochemical rate-determining step of aqueous pyrite oxidation. Geochim. Cosmochim. Acta 1994, 58, 5443-5454. [CrossRef]

7. Biagioni, C.; D’Orazio, M.; Vezzoni, S.; Dini, A.; Orlandi, P. Mobilization of Tl-Hg-As-Sb-(Ag,Cu)-Pb sulfosalt melts during low-grade metamorphism in the Alpi Apuane (Tuscany, Italy). Geology 2013, 41, 747-750. [CrossRef]

8. D'Orazio, M.; Biagioni, C.; Dini, A.; Vezzoni, S. Thallium-rich pyrite ores from the Apuan Alps, Tuscany, Italy: Constraints for their origin and environmental concerns. Miner. Deposita 2017, 52, 687-707. [CrossRef]

9. George, L.L.; Biagioni, C.; D'Orazio, M.; Cook, N.J. Textural and trace element evolution of pyrite during greenschist facies metamorphic recrystallization in the southern Apuan Alps (Tuscany, Italy): Influence on the formation of Tl-rich sulfosalt melt. Ore Geol. Rev. 2018, 102, 59-105. [CrossRef]

10. Perotti, M.; Petrini, R.; D’Orazio, M.; Ghezzi, L.; Giannecchini, R.; Vezzoni, S. Thallium and other potentially toxic elements in the Baccatoio Stream Catchment (Northern Tuscany, Italy) receiving drainages from abandoned mines. Mine Water Environ. 2018, 37, 431-441. [CrossRef]

11. Ghezzi, L.; D’Orazio, M.; Doveri, M.; Lelli, M.; Petrini, R.; Giannecchini, R. Groundwater and potentially toxic elements in dismissed mining area: Thallium contamination of drinking spring water in the Apuan Alps (Tuscany, Italy). J. Geochem. Expl. 2019, 197, 84-92. [CrossRef] 
12. D'Orazio, M.; Campanella, B.; Bramanti, E.; Onor, M.; Vianello, G.; Vittori-Antisari, L.; Petrini, R. Thallium pollution in water, soils and plants from a past-mining site of Tuscany: Sources, transfer processes and toxicity. J. Geochem. Expl. 2020, $209,106434$. [CrossRef]

13. Giannecchini, R.; D'Amato Avanzi, G. Historical research as a tool in estimating hydrogeological hazard in a typical small alpine-like area: The example of the Versilia River basin (Apuan Alps, Italy). Phys. Chem. Earth 2012, Parts A/B/C 49, 32-43. [CrossRef]

14. Piccini, L.; Pranzini, G.; Tedici, L.; Forti, P. Le risorse idriche dei complessi carbonatici del comprensorio apuo-versiliese. Quaderni di Geologia Applicata 1999, 6, 61-78.

15. D'Achiardi, A. Mineralogia della Toscana; Tipografia Nistri: Pisa, Italy, 1872; Volume 1, p. 276.

16. Biagioni, C.; Mauro, D.; Pasero, M. Sulfates from the pyrite ore deposits of the Apuan Alps (Tuscany, Italy): A review. Minerals 2020, 10, 1092. [CrossRef]

17. Frau, F. The formation-dissolution-precipitation cycle of melanterite at the abandoned pyrite mine of Genna Luas in Sardinia, Italy: Environmental implications. Mineral. Mag. 2000, 64, 995-1006. [CrossRef]

18. Valente, T.M.; Gomes, C.L. Occurrence, properties and pollution potential of environmental minerals in acid mine drainage. Sci. Tot. Environ. 2009, 407, 1135-1152. [CrossRef]

19. Jerz, J.K.; Rimstidt, J.D. Efflorescent iron sulfate minerals: Paragenesis, relative stability, and environmental impact. Am. Mineral. 2003, 88, 1919-1932. [CrossRef]

20. Hammarstrom, J.M.; Seall II, R.R.; Meier, A.L.; Kornfeld, J.M. Secondary sulfate minerals associated with acid drainage in the eastern US: Recycling of metals and acidity in surficial environments. Chem. Geol. 2005, 215, 407-431. [CrossRef]

21. Carmignani, L.; Dessau, G.; Duchi, G. I giacimenti a barite, pirite ed ossidi di ferro delle Alpi Apuane. Studio minerogenetico e strutturale. Boll. Soc. Geol. It. 1976, 95, 1009-1061.

22. Biagioni, C.; D’Orazio, M.; Fulignati, P.; George, L.L.; Mauro, D.; Zaccarini, F. Sulfide melts in ore deposits from low-grade metamorphic settings: Insights from fluid and Tl-rich sulfosalt microinclusions from the Monte Arsiccio mine (Apuan Alps, Tuscany, Italy). Ore Geol. Rev. 2020, 123, 103589. [CrossRef]

23. Biagioni, C.; Bindi, L.; Mauro, D.; Pasero, M. Crystal-chemistry of sulfates from the Apuan Alps (Tuscany, Italy). IV. Giacovazzoite, $\mathrm{K}_{5} \mathrm{Fe}^{3+}{ }_{3} \mathrm{O}\left(\mathrm{SO}_{4}\right)_{6}\left(\mathrm{H}_{2} \mathrm{O}\right)_{9} \cdot \mathrm{H}_{2} \mathrm{O}$, the natural analogue of the $\beta$-Maus's Salt and its dehydration product. Phys. Chem. Miner. 2020, 47, 7. [CrossRef]

24. Biagioni, C.; Bindi, L.; Mauro, D.; Hålenius, U. Crystal chemistry of sulfates from the Apuan Alps (Tuscany, Italy). V. Scordariite, $\mathrm{K}_{8}\left(\mathrm{Fe}^{3+}{ }_{0.67 \square 0.33}\right)\left[\mathrm{Fe}^{3+}{ }_{3} \mathrm{O}\left(\mathrm{SO}_{4}\right)_{6}\left(\mathrm{H}_{2} \mathrm{O}\right)_{3}\right]_{2}\left(\mathrm{H}_{2} \mathrm{O}\right)_{11}$ : A new metavoltine-related mineral. Minerals 2019, 9, 702. [CrossRef]

25. Biagioni, C.; Bindi, L.; Kampf, A.R. Crystal chemistry of sulfates from the Apuan Alps (Tuscany, Italy). VII. Magnanelliite, $\mathrm{K}_{3} \mathrm{Fe}^{3+}{ }_{2}\left(\mathrm{SO}_{4}\right)_{4}(\mathrm{OH})\left(\mathrm{H}_{2} \mathrm{O}\right)_{2}$, a new sulfate from the Monte Arsiccio mine. Minerals 2019, 9, 779. [CrossRef]

26. Mauro, D.; Biagioni, C.; Pasero, M.; Zaccarini, F. Crystal-chemistry of sulfates from the Apuan Alps, Tuscany, Italy. VIII. New data on khademite, $\mathrm{Al}\left(\mathrm{SO}_{4}\right) \mathrm{F}\left(\mathrm{H}_{2} \mathrm{O}\right)_{5}$. Mineral. Mag. 2020, 84, 540-546. [CrossRef]

27. Mauro, D.; Biagioni, C.; Pasero, M.; Skogby, H.; Zaccarini, F. Redefinition of coquimbite, $\mathrm{AlFe}^{3+}{ }_{3}\left(\mathrm{SO}_{4}\right)_{6}\left(\mathrm{H}_{2} \mathrm{O}\right)_{12} \cdot 6 \mathrm{H}_{2} \mathrm{O} . \mathrm{Mineral}$. Mag. 2020, 84, 275-282. [CrossRef]

28. Wojdyr, M. Fityk: A general-purpose peak fitting program. J. Appl. Crystallogr. 2010, 43, 1126-1128. [CrossRef]

29. Hawthorne, F.C.; Krivovichev, S.V.; Burns, P.C. The crystal chemistry of sulfate minerals. Sulfate Minerals-Crystallography, geochemistry and environmental significance. Rev. Mineral. Geochem. 2000, 40, 1-101. [CrossRef]

30. Frost, R.L.; Kloprogge, J.T. Raman microscopy study of kalinite, tschermigite and lonecreekite at 298 and 77 K. N. Jahr. Mineral. Monat. 2001, 2001, 27-40.

31. Biagioni, C.; Mauro, D.; Pasero, M.; Bonaccorsi, E.; Lepore, G.O.; Zaccarini, F.; Skogby, H. Crystal-chemistry of sulfates from the Apuan Alps (Tuscany, Italy). VI. Tl-bearing alum-(K) and voltaite from the Fornovolasco mining complex. Am. Mineral. 2020, 105, 1088-1098. [CrossRef]

32. Frost, R.L.; Žigovečki Gobac, Ž.; López, A.; Xi, Y.; Scholz, R.; Lana, C.; Fernandes Lima, R.M. Characterization of the sulphate mineral coquimbite, a secondary iron sulphate from Javier Ortega mine, Lucanas Province, Peru-Using infrared, Raman spectroscopy and thermogravimetry. J. Mol. Struct. 2014, 1063, 251-258. [CrossRef]

33. Locke, A.J.; Martens, W.N.; Frost, R.L. Natural halotrichites-An EDX and Raman spectroscopic study. J. Raman Spectr. 2007, 38, 1429-1435. [CrossRef]

34. Mauro, D.; Biagioni, C.; Pasero, M.; Skogby, H. Crystal-chemistry of sulfates from the Apuan Alps (Tuscany, Italy). III. Mg-rich sulfate assemblages from the Fornovolasco mining complex. Atti Soc. Tosc. Sci. Nat. Mem. 2019, 126, 33-44.

35. Mauro, D.; Biagioni, C.; Pasero, M. Crystal-chemistry of sulfates from Apuan Alps (Tuscany, Italy). I. Crystal structure and hydrogen bond system of melanterite, $\mathrm{Fe}\left(\mathrm{H}_{2} \mathrm{O}\right)_{6}\left(\mathrm{SO}_{4}\right) \cdot \mathrm{H}_{2} \mathrm{O}$. Period. Mineral. 2018, 87, 89-96.

36. Frost, R.L.; Palmer, S.J.; Čejka, J.; Sejkora, J.; Plášil, J.; Jebavá, I.; Keeffe, E.C. A Raman spectroscopic study of $\mathrm{M}^{2+} \mathrm{M}^{3+}$ sulphate minerals, römerite $\mathrm{Fe}^{2+} \mathrm{Fe}^{3+}{ }_{2}\left(\mathrm{SO}_{4}\right)_{4} \cdot 14 \mathrm{H}_{2} \mathrm{O}$ and botryogen $\mathrm{Mg}^{2+} \mathrm{Fe}^{3+}\left(\mathrm{SO}_{4}\right)_{2}(\mathrm{OH}) \cdot 7 \mathrm{H}_{2} \mathrm{O}$. J. Raman Spectr. 2011, 42, 825-830. [CrossRef]

37. Mauro, D.; Biagioni, C.; Pasero, M.; Zaccarini, F. Crystal-chemistry of sulfates from Apuan Alps (Tuscany, Italy). II. Crystal structure and hydrogen bonding system of römerite, $\mathrm{Fe}^{2+} \mathrm{Fe}^{3+}{ }_{2}\left(\mathrm{SO}_{4}\right)_{4}\left(\mathrm{H}_{2} \mathrm{O}\right)_{14}$. Atti Soc. Tosc. Sci. Nat. Mem. 2018, 125, 5-11.

38. Košek, F.; Edwards, H.G.M.; Jehlička, J. Raman spectroscopic vibrational analysis of the complex ion sulfates clairite, metavoltine, and voltaite from the burning coal dump Anna I, Alsdorf, Germany. J. Raman Spectr. 2020, 51, 1454-1461. [CrossRef] 
39. Košek, F.; Culca, A.; Žáček, V.; Laufek, F.; Škoda, R.; Jehlička, J. Native alunogen: A Raman spectroscopic study of a well-described specimen. J. Mol. Struct. 2018, 1157, 191-200. [CrossRef]

40. Taylor, S.R.; McLennan, S.M. The geochemical evolution of the continental crust. Rev. Geophys. 1995, 33, 241-265. [CrossRef]

41. Vezzoni, S.; Pieruccioni, D.; Galanti, Y.; Biagioni, C.; Dini, A. Permian hydrothermal alteration preserved in polymetamorphic basement and constraints for ore-genesis (Alpi Apuane, Italy). Geosciences 2020, 10, 399. [CrossRef]

42. Romero, A.; González, I.; Galán, E. The role of efflorescent sulfates in the storage of trace elements in stream waters polluted by acid mine-drainage: The case of Peña del Hierro, southwestern Spain. Can. Mineral. 2006, 44, 1431-1446. [CrossRef]

43. Nieva, N.E.; Garcia, M.G.; Borgnino, L.; Borda, L.G. The role of efflorescent salts associated with sulfide-rich mine wastes in the short-term cycling of arsenic: Insights from XRD, XAS, and $\mu$-XRF studies. J. Hazard. Mater. 2021, 404, 124158. [CrossRef] [PubMed]

44. Rutstein, M.S. Nickeloan melanterite from Sudbury Basin. Am. Mineral. 1980, 65, 968-969.

45. Li, W.; Chen, G. Lishizhenite-A new zinc sulphate mineral. Acta Mineral. Sin. 1990, 10, $299-305$.

46. Li, W.; Chen, G.; Sun, S. Zincovoltaite-A new sulphate mineral. Acta Mineral. Sin. 1987, 7, 307-312.

47. Nyburg, S.C.; Steed, J.W.; Aleksovska, S.; Petruševski, V.M. Structure of the alums. I. On the sulfate group disorder in the $\alpha$-alums. Acta Crystallogr. 2000, B56, 204-209. [CrossRef] [PubMed]

48. Pemberton, H.E. New minerals from California. Mineral. Rec. 1971, 2, 152-161.

49. Biagioni, C.; Orlandi, P.; Pasero, M. Ankangite from the Monte Arsiccio mine (Apuan Alps, Tuscany, Italy): Occurrence, crystal structure, and classification problems in cryptomelane group minerals. Period. Mineral. 2009, 78, 3-11.

50. Biagioni, C.; Orlandi, P.; Pasero, M.; Nestola, F.; Bindi, L. Mapiquiroite, $(\mathrm{Sr}, \mathrm{Pb})(\mathrm{U}, \mathrm{Y}) \mathrm{Fe}_{2}\left(\mathrm{Ti}_{1}, \mathrm{Fe}^{3+}\right){ }_{18} \mathrm{O}_{38}$, a new member of the crichtonite group from the Apuan Alps, Tuscany, Italy. Eur. J. Mineral. 2014, 26, 427-437. [CrossRef]

51. Biagioni, C.; Bonaccorsi, E.; Perchiazzi, N.; Hålenius, U.; Zaccarini, F. Derbylite and graeserite from the Monte Arsiccio mine, Apuan Alps, Tuscany, Italy: Occurrence and crystal-chemistry. Mineral. Mag. 2020, 84, 766-777. [CrossRef]

52. Hawkes, S.J. All positive ions give acid solutions in water. J. Chem. Educ. 1996, 73, 516-517. [CrossRef]

53. Hurowitz, J.A.; Tosca, N.J.; Dyar, M.D. Acid production by $\mathrm{FeSO}_{4} \cdot n \mathrm{H}_{2} \mathrm{O}$ dissolution and implications for terrestrial and martian aquatic systems. Am. Mineral. 2009, 94, 409-414. [CrossRef]

54. Giles, D.E.; Mohapatra, M.; Issa, T.B.; Anand, S.; Singh, P. Iron and aluminium based adsorption strategies for removing arsenic from water. J. Environ. Manag. 2011, 92, 3011-3022. [CrossRef] [PubMed] 